\title{
Investigation of the Occupational Exposure to Blood-borne Pathogens of Staff at a Third-class Specialist Hospital in 2015- 2018: a Retrospective Study
}

\author{
Yuanyi Ji \\ West China School of Public Health and West China Fourth University Hospital, Sichuan University \\ Junbo Huang \\ West China School of Public Health and West China Fourth University Hospital, Sichuan University \\ Guoguo Jiang \\ Chengdu Second People's Hospital \\ Qiaolan Liu \\ West China School of Public Health and West China Fourth University Hospital, Sichuan University \\ Dalei Xiao \\ West China Second University Hospital of Sichuan University \\ Jianjun Deng ( $\sim$ dengjj@163.com ) \\ West China Second University Hospital of Sichuan University
}

\section{Research Article}

Keywords: Occupational exposure to blood-borne pathogens, Monitoring system, Protection system

Posted Date: July 20th, 2021

DOl: https://doi.org/10.21203/rs.3.rs-96888/v2

License: @ (i) This work is licensed under a Creative Commons Attribution 4.0 International License. Read Full License

Version of Record: A version of this preprint was published at Scientific Reports on January 27th, 2022. See the published version at https://doi.org/10.1038/s41598-022-05436-z. 


\section{Abstract}

Background To understand the current situation of occupational exposure to blood-borne pathogens in a women's and children's hospital and analyze the causes to provide a scientific basis for improving occupational exposure prevention and control measures.

Methods We analyzed occupational exposure to blood-borne pathogens in a third-class women's and children's hospital from 2015 to 2018, considering the workers' occupational categories and length of service; the sites, types, and causes of exposure; and the pathogens of the source patients.

Results From 2015 to 2018, there were 146 cases of occupational exposure to blood-borne pathogens, mainly from sharpinstrument injuries (82.2\%). Trainees represented the highest proportion of occupational exposure (30.1\%), followed by nurses (29.5\%). Occupational exposure among staff with less than one year of service accounted for $43.2 \%$ of cases. Fisher's exact test showed that different occupational groups had different types of occupational exposure, and nurses had the highest proportion of blood and body fluid exposure $(P=0.008)$. Different occupational groups faced exposure to different types of pathogens: medical staff were more likely than workmen to be exposed to hepatitis $B$, while workmen were more likely than medical staff to be exposed to unknown pathogens; these differences were statistically significant $(P<0.001)$. Health records were established for all cases of occupational exposure to blood-borne pathogens, and no staff members contracted a bloodborne disease due to occupational exposure.

Conclusions In order to reduce occupational exposure, regular training in occupational protection for junior medical staff and workers should be strengthened, the monitoring and protection system of occupational exposure to blood-borne pathogens improved, standard prevention measures strengthened, operations standardized, safe injection equipment provided, and comprehensive measures taken.

\section{Introduction}

Occupational exposure to blood-borne pathogens refers to the state in which workers encounter blood or other potentially infectious substances containing blood-borne pathogens through the eyes, mouth, nose or other mucous membranes; damaged skin; or parenteral routes during occupational activities [1]. In the current medical environment in China, hospital staff members are faced with a limited number of doctors relative to the number of patients, an excessive workload and strained doctor-patient relationships and are often in a state of intense activity and high risk [2]. In the event of occupational exposure, the physical and mental health of medical staff could be severely impaired. The "Guidelines for the Prevention of Occupational Exposure to Bloodborne Pathogens", proposed in 2009, and the "Occupational Disease Classification and Catalogue", revised in 2013 to include AIDS among medical personnel due to occupational exposure, indicate the state's increasing attention to the occupational exposure of medical personnel $[1,3]$. Therefore, to fully understand the current situation of occupational exposure to blood-borne pathogens among the staff at a women's and children's hospital, reduce the risk of such exposure, and improve monitoring and protection against this threat, the present study retrospectively analyzed 146 cases of occupational exposure in a women's and children's hospital from 2015-2018.

\section{Methods}

\section{Source}

This study examined a total of 146 cases of occupational exposure to blood-borne pathogens that occurred in a third-class women's and children's hospital from January 2015 to December 2018.

\section{Methods and statistical analysis}


Data on exposure to blood-borne pathogens in 2015-2018 were collected from medical personnel occupational exposure case registration forms, which include basic personal information, occupational category, location, type, cause, source of pathogens, emergency treatment after exposure and post exposure prophylaxis; follow-up surveys were conducted for each case of occupational exposure. The informed written consent was obtained from all participants. The ethics approval of this study was obtained from Medical Ethical Committee of West China School of Public Health and West China Fourth University Hospital that approved the research, confirm that all research was performed in accordance with relevant guidelines/regulations.

The medical staff occupational exposure case registration form was uniformly coded; data were entered using EpiData 3.1 software, and data collation, statistical description and statistical analysis were performed using SPSS 20.0. The data were statistically described by rates or composition ratios. Comparisons between the data groups were performed by the $\square^{2}$ test or Fisher's exact test, and the significance level was $a=0.05$.

\section{Results}

Table 1 describes the profile of the sample group. There were 146 cases of occupational exposure to blood-borne pathogens in 2015-2018, involving 23 men (15.8\%) and 123 women (84.2\%). The largest occupational category consisted of internship trainees and trainers, accounting for $30.1 \%$ (44), followed by nurses, accounting for $29.5 \%$ (43). Less experienced workers represented more cases of blood-borne occupational exposure; workers with less than 5 years of tenure accounted for $71.2 \%$ (104) of the total number of cases, and workers with less than one year of tenure accounted for $43.2 \%$ (63).

Table 1

Basic situation of the occupational exposure of hospital staff to blood-borne pathogens, 2015-2018 ( $\mathrm{N}=146)$

\begin{tabular}{|c|c|c|}
\hline Variable & & $N(\%)$ \\
\hline \multirow[t]{2}{*}{ Sex } & Man & $23(15.8)$ \\
\hline & Woman & $123(84.2)$ \\
\hline \multirow[t]{5}{*}{ Occupational category } & Clinician & $24(16.4)$ \\
\hline & Nurse & $43(29.5)$ \\
\hline & Medical technician & $4(2.7)$ \\
\hline & Workman & $31(21.2)$ \\
\hline & Internship trainee or trainer & $44(30.1)$ \\
\hline \multirow[t]{4}{*}{ Length of service } & $\leq 1$ year & $63(43.2)$ \\
\hline & $1 \sim \leq 5$ years & $41(28.1)$ \\
\hline & $5 \sim \leq 10$ years & $23(15.8)$ \\
\hline & $>10$ years & $19(13.0)$ \\
\hline
\end{tabular}

Table 2 describes the types of occupational exposure to blood-borne pathogens among the hospital staff. Of the 146 cases, 119 involved sharp injuries, accounting for $82.2 \%$, and 27 were blood fluid exposures, accounting for $17.8 \%$. The sharp injuries included 47 cases involving syringe needles, 21 involving scalp-vein needles, 23 involving suture needles, 10 involving scalpels, and 18 involving other sharps. Table 3 presents the timing of blood-borne occupational exposure. These events were concentrated during operations; during examination, treatment, and other nursing activities after operation; after the completion of treatment; and during disposal of waste. The most common time of exposure was during surgery (sewing/cutting) (19.8\%). Exposure also occurred due to sharp injuries after operations, either when staff members were stabbed by an improperly placed sharp object (9.6\%) or when nurses were treating and checking on patients $(9.6 \%)$. Occupational exposure occurred mainly in the ward $(28.1 \%)$ and the operating room $(26.7 \%)$. 
Table 2

Types of occupational exposure to blood-borne pathogens among hospital staff $(N=146)$

\begin{tabular}{|llc|}
\hline Type & & $\mathbf{N}(\%)$ \\
\hline Sharps injuries & Syringe needle & $47(32.2)$ \\
\cline { 2 - 3 } & Scalp needle & $21(14.4)$ \\
\cline { 2 - 3 } & Suture needle & $23(15.8)$ \\
\cline { 2 - 3 } & Scalpel & $10(6.8)$ \\
\cline { 2 - 3 } & Other sharps & $18(12.3)$ \\
\hline Exposure to blood and body fluids & Exposure of blood and body fluids to skin and mucosa & $27(18.5)$ \\
\hline
\end{tabular}

Table 3

Occupational exposure to blood-borne pathogens, top 10 ranking $(\mathrm{N}=146)$

\begin{tabular}{|ll|}
\hline Exposure time & $\mathbf{N}(\%)$ \\
\hline During surgery (suture/incision) & $29(19.8)$ \\
\hline Stabbed by improperly placed sharp objects after operation & $14(9.6)$ \\
\hline Examination, treatment, and other nursing activities after operation & $14(9.6)$ \\
\hline During disposal of sharp objects & $11(7.5)$ \\
\hline Handling the trans-shipment of medical waste & $11(7.5)$ \\
\hline Venous puncture & $10(6.8)$ \\
\hline Needle removal, needle separation and syringe at the end of the infusion & $10(6.8)$ \\
\hline Discarding sharp objects such as needles & $9(6.2)$ \\
\hline Cooperating with other personnel & $6(4.1)$ \\
\hline Transferring sharps & $4(2.7)$ \\
\hline
\end{tabular}

The occupational exposure data of the 146 cases (Table 4) showed that the main blood-borne infection responsible for occupational exposure among hospital staff was hepatitis B (30.8\%), followed by HIV/AIDS (7.5\%); in another $36.3 \%$ of cases, the pathogen status of the source patient was uncertain.

Table 4

Distribution of pathogens in source patients of occupational exposure to blood-borne pathogens $(\mathrm{N}=146)$

\begin{tabular}{|ll|}
\hline Pathogen species & $\mathbf{N}(\%)$ \\
\hline Negative & $25(17.1)$ \\
\hline Hepatitis B & $45(30.8)$ \\
\hline HIV/AIDS & $3(2.1)$ \\
\hline Syphilis & $11(7.5)$ \\
\hline Unknown pathogen & $53(36.3)$ \\
\hline
\end{tabular}


Fisher's exact test (Table 5) showed that different groups sustained different types of occupational exposure. Nurses had a significantly higher proportion of blood fluid exposure than other occupational groups $\left(\square^{2}=12.937, P=0.008\right)$. The types of occupational exposure and pathogens also differed across occupational groups. Most medical workers exposed to occupational infection were exposed to hepatitis $B$, whereas workmen were mainly exposed to unknown pathogens. The difference was statistically significant $\left(\square^{2}=55.344, P<0.001\right)$ (Table 6).

Table 5

Occupational exposure analysis of staff with different work experience and occupational category $(\mathrm{N}=146)$

\begin{tabular}{|c|c|c|c|c|c|}
\hline \multirow[t]{2}{*}{ Variable } & & \multicolumn{2}{|l|}{ Types } & \multirow{2}{*}{$\begin{array}{l}\text { Pearson } \\
\square^{2}\end{array}$} & \multirow[t]{2}{*}{$P$-value } \\
\hline & & $\begin{array}{l}\text { Sharp injury } \mathrm{N} \\
(\%)\end{array}$ & $\begin{array}{l}\text { Exposure to blood and body } \\
\text { fluids }\end{array}$ & & \\
\hline \multirow{5}{*}{$\begin{array}{l}\text { Occupational } \\
\text { category }\end{array}$} & Clinicians & $17(70.8)$ & $7(29.2)$ & \multirow[t]{5}{*}{12.937} & \multirow[t]{5}{*}{0.008} \\
\hline & Nurse & $30(69.8)$ & $13(30.2)$ & & \\
\hline & Medical technicians & $3(75.0)$ & $1(25.0)$ & & \\
\hline & Workman & $30(96.8)$ & $1(3.2)$ & & \\
\hline & $\begin{array}{l}\text { Internship trainee or } \\
\text { trainer }\end{array}$ & 39 (88.6) & $5(11.4)$ & & \\
\hline \multirow[t]{4}{*}{ Length of service } & $\leq 1$ year & $53(84.1)$ & 10 (15.9) & \multirow[t]{4}{*}{5.835} & \multirow[t]{4}{*}{0.115} \\
\hline & $1 \sim \leq 5$ years & $18(90.0)$ & $2(10.0)$ & & \\
\hline & $5 \sim \leq 10$ years & $19(90.5)$ & $2(9.5)$ & & \\
\hline & $>10$ years & $29(69.0)$ & $13(31.0)$ & & \\
\hline
\end{tabular}


Table 6

Analysis of the pathogens workers with different work experiences and occupational categories were exposed to $(N=146)$

\begin{tabular}{|c|c|c|c|c|c|c|c|c|c|}
\hline \multirow[t]{2}{*}{ Variable } & & \multicolumn{6}{|c|}{ Exposure pathogens } & \multirow{2}{*}{$\begin{array}{l}\text { Pearson } \\
\square^{2}\end{array}$} & \multirow[t]{2}{*}{$P$-value } \\
\hline & & Negative & $\begin{array}{l}\text { Hepatitis } \\
\text { B }\end{array}$ & $\begin{array}{l}\text { Hepatitis } \\
\mathrm{C}\end{array}$ & HIV/AIDS & Syphilis & $\begin{array}{l}\text { Unknown } \\
\text { pathogen }\end{array}$ & & \\
\hline \multirow[t]{5}{*}{$\begin{array}{l}\text { Occupational } \\
\text { category }\end{array}$} & Clinician & $1(4.2)$ & $\begin{array}{l}12 \\
(50.0)\end{array}$ & $0(0.0)$ & $5(20.8)$ & $2(8.3)$ & $4(16.7)$ & \multirow[t]{5}{*}{55.227} & \multirow[t]{5}{*}{$<0.001$} \\
\hline & Nurse & $6(14.0)$ & $\begin{array}{l}16 \\
(37.2)\end{array}$ & $3(7.0)$ & $4(9.3)$ & $2(4.7)$ & $12(27.9)$ & & \\
\hline & $\begin{array}{l}\text { Medical } \\
\text { technician }\end{array}$ & $0(0.0)$ & $1(25.0)$ & $0(0.0)$ & $0(0.0)$ & $1(25)$ & $2(50.0)$ & & \\
\hline & Workman & $9(29.0)$ & $0(0.0)$ & $0(0.0)$ & $0(0.0)$ & $0(0.0)$ & $22(71.0)$ & & \\
\hline & $\begin{array}{l}\text { Internship } \\
\text { trainee or } \\
\text { trainer }\end{array}$ & $9(20.5)$ & $\begin{array}{l}16 \\
(36.4)\end{array}$ & $0(0.0)$ & $2(4.5)$ & $4(9.1)$ & $13(29.5)$ & & \\
\hline \multirow[t]{4}{*}{$\begin{array}{l}\text { Length of } \\
\text { service }\end{array}$} & $\leq 1$ year & $\begin{array}{l}11 \\
(17.5)\end{array}$ & $\begin{array}{l}21 \\
(33.3)\end{array}$ & $0(0.0)$ & $3(4.8)$ & $6(9.5)$ & $22(34.9)$ & \multirow[t]{4}{*}{16.777} & \multirow[t]{4}{*}{0.428} \\
\hline & $\begin{array}{l}1 \sim \leq 5 \\
\text { years }\end{array}$ & $7(17.1)$ & $\begin{array}{l}11 \\
(26.8)\end{array}$ & $2(4.9)$ & $2(4.9)$ & $0(0.0)$ & $19(46.3)$ & & \\
\hline & $\begin{array}{l}5 \sim \leq 10 \\
\text { years }\end{array}$ & $3(13.0)$ & $7(30.4)$ & $1(4.3)$ & $3(13.0)$ & $3(13.0)$ & $6(26.1)$ & & \\
\hline & $>10$ years & $4(21.1)$ & $6(31.6)$ & $0(0.0)$ & $3(15.8)$ & $0(0.0)$ & $6(31.6)$ & & \\
\hline
\end{tabular}

Of the 146 individuals who experienced occupational exposure to blood-borne pathogens, 135 (92.5\%) were subjected to emergency treatment (extrusion, rinsing, disinfection, and dressing) after exposure. All exposed persons underwent extensive immunological testing (including tests for hepatitis B, hepatitis $\mathrm{C}, \mathrm{HIV}$ and syphilis), which can be used as a baseline result after exposure, and risk assessment was carried out based on the source patient's pathogen, the nature of the exposure, the staff member's autoimmune status, and rational preventive medication. Occupational exposure health records were established for all cases of occupational exposure to blood-borne pathogens, and the exposed staff members were followed up regularly; no staff members were infected with blood-borne diseases due to occupational exposure.

\section{Discussion}

\section{High-risk groups for occupational exposure}

Between 2015 and 2018, a total of 146 cases of occupational exposure to blood-borne pathogens occurred in the hospital. Interns, internship trainees, trainers and nurses were the most commonly exposed occupations, similar to the results of Chinese and international research [2,4-7]. Most of the staff members involved in the clinical diagnosis and treatment process are involved in frontline work. Medical staff who are in internship training and regular training spend a relatively short time in the hospital. These staff are relatively unfamiliar with the hospital environment and equipment and are especially prone to occupational exposure. Teaching hospitals also receive more interns and training personnel than other hospitals do [8]. In addition, the survey found that less experienced staff members represented a high proportion of blood-borne occupational exposure cases, which was related to their relatively low attentiveness, skill levels, and awareness of self-protection measures [9]. Pre-employment and on-the-job training for less experienced staff and intern trainees should be strengthened. Different occupational categories had different types of occupational exposures, and the differences were statistically significant. Nurses represent a higher proportion of blood fluid exposure cases than other types of medical staff, suggesting that different intervention strategies should be targeted to different occupational categories to reduce the risk of occupational exposure. 
Notably, workmen face the third highest risk of occupational exposure, suggesting a high risk of occupational exposure among that group, and workers involved in the collection and disposal of medical waste are relatively vulnerable [10].

\section{Exposure type and time}

Concerning the type of occupational exposure, sharp injuries accounted for the most cases. The sharps that cause sharp injuries are mainly syringe needles, scalp-vein needles, suture needles and scalpels, which is consistent with the results of Cho $\mathrm{E}$ [11]. Exposures occur mainly during operations (treatment, examination, surgery) and the handling and disposal of waste, and sharp injuries are especially likely to occur during invasive operations and operations with time constraints [12]. Often, sharp objects that are no longer being used and that have been improperly placed are involved in cases of exposure. This misplacement may be related to the specifications and convenience of sharps boxes. Sharps boxes should have different specifications and be convenient to use, and they should be placed within arm's reach and in the field of view [13]. It is recommended that hospital staff strictly implement standardized prevention and operation processes.

\section{Source disease analysis}

The investigation showed that the main blood-borne infection to which the hospital staff members were exposed was hepatitis $B$, as found in other studies [14-16]. China is a country with a high incidence of hepatitis $B$ relative to the global level. The most effective way to protect workers from occupational exposure to the hepatitis B virus is vaccination against hepatitis B. Therefore, the immunization of hospital staff must be improved, with the aim of full coverage. Notably, the pathogens of the source patients involved in $36.3 \%$ of the occupational exposure cases were unclear. In addition, according to Fisher's exact test, different occupational groups faced different types of infection from occupational exposure, and the difference was statistically significant. Medical staff were more likely than workmen to be exposed to hepatitis $B$, and workmen were exposed mainly to unknown pathogens. Workmen and medical staff are both high-risk groups; their awareness of occupational protection should be strengthened, and the process for handling medical waste should be standardized.

\section{Conclusions}

\section{Occupational exposure protection strategy}

(1) Improve the hospital occupational protection management system and clarify the responsibilities of all relevant departments. Hospitals should establish and provide timely updates to the occupational exposure protection measures and treatment procedures for blood-borne pathogens in ways that correspond to the actual conditions at the hospital to protect the health and rights of hospital staff.

(2) Carry out diverse and targeted vocational training and education, such as pre-employment training, on-the-job training, special education, emergency drills, daily department meetings, daily in-house teleconferences and online training and assessment. Each department should participate in a medical quality assessment, and the safety awareness of all types of staff should be improved; the entire hospital staff should be included in these efforts. Moreover, each department should be conveniently equipped with personal protective equipment and sharps boxes according to its occupational exposure risks.

(3) Provide safe working environments, equipment and supplies, such as safe injection equipment and various types of sharps, to reduce the risk of occupational exposure.

(4) Implement an immunization system and inoculate staff against hepatitis B to prevent hepatitis B infection through occupational exposure. Each hospital staff member should be vaccinated according to his or her own immunization conditions.

(5) Use behavioral changes to reduce the high-risk behaviors of medical staff, for example, by prohibiting the reuse of trocar caps, ensuring that sharps boxes are never more than 3/4 full and remain closed, strengthening preventive measures, and 
standardizing operation protocols.

(6) Improve the monitoring and protection system for occupational exposure to blood-borne pathogens and establish occupational exposure health records for each hospital staff member to reduce the risk of occupational exposure.

\section{Declarations}

\section{Acknowledgments}

None. We gratefully thank China National Natural Science Foundation and Sichuan University for funding the study.

\section{Author contributions}

Data curation: Guoguo Jiang, Junbo Huang.

Methodology: Dalei Xiao, Qiaolan Liu.

Writing-original draft: Yuanyi Ji.

Writing-review \& editing: Jianjun Deng.

\section{Consent for publication}

Not applicable

\section{Availability of data and materials}

The datasets used and/or analyzed during the current study are available from the corresponding author on reasonable request.

\section{Financial support}

This work was supported by the National Natural Science Foundation of China (No. 30972546 and 81472994).

\section{Ethics approval and consent to participate}

The medical staff provided verbal and written consent to participate and the ethics approval of this study was obtained from Medical Ethical Committee of Sichuan University, China (No.20140307).

\section{Conflicts of interest}

All authors report that they have no conflicts of interest relevant to this article.

\section{References}

1. Zhang M. "Guidelines for the Protection of Occupational Contact of Bloodborne Pathogens" and Its Interpretation. Chinese Nursing Management,2010,10(07):10-12.

2. Sun J, Xu H, Gu AM, et al. Investigation and Analysis of Occupational Exposure and Protection of Medical Staff in China.Chinese $\mathrm{J}$ of Infection Control,2016,15(09):681-685.

3. Xiao Q. The latest Classification and Catalogue of Occupational Diseases in 2014. Safety \& Health,2014(06):36-37.

4. Ran SS. Study on current status and preventive strategy of occupational exposure in a women and children's hospital during 2011-2015.J Mod Med Health, 2017,33(13):1958-1960.

5. Różańska A, Szczypta A, Baran M,et al. Healthcare workers' occupational exposure to bloodborne pathogens: a 5-year observation in selected hospitals of the Małopolska province. Int J Occup Med Environ Health,2014,27(5):747-756. 
6. Kassa G, Selenic D, Lahuerta M,et al. Occupational exposure to bloodborne pathogens among health care workers in Botswana: Reporting and utilization of postexposure prophylaxis. Am J Infect Control.2016,44(8):879-885.

7. Wang YJ『Meng ZH®Zheng XF『et al. The status of occupational blood and infectious body fluids exposure China: a 5-year review. Transfus Med.2015(25)6:399-405.

8. Wang YT,Qiao F,Huang WZ, et al. Analysis of sharp instrument injuries among healthcare staff in a comprehensive teaching hospital from 2011 to 2014.West China Medical Journal, 2017,32(03):348-351.

9. Henk F, Van der Molen, Koos A H, et al. Better effect of the use of a needle safety device in combination with an interactive workshop to prevent needle stick injuries. Safety Science,2011,49(8)凶1180-1186.

10. Rvbacki M, Piekarska A, Wiszniewska M, et al. Work safety among Polish health care workers in respect of exposure to bloodborne pathogens. Med Pr.2013,64(1):1-10.

11. Cho $\mathrm{E}$, Lee $\mathrm{H}$, Choi $\mathrm{M}$, et al. Factors associated with needlestick and sharp injuries among hospital nurses: a cross-sectional questionnaire survey. Int J Nurs Stud.2013,50(8):1025-1032.

12. Bakaeen F, Awad S, Albo D, et al. Epidemiology of exposure to blood borne pathogens on a surgical service. Am J Surg.2006,192(5):18-21.

13. Hutin Y, Hauri A, Chiarello L, et al. Best infection control practices for intradermal, subcutaneous, and intramuscular needle injection.Bull World Health Orqan.2003,81(7):491-500.

14. Deuffic-Burban S, Delarocque-Astagneau E, Abiteboul D. Blood-borne viruses in health care workers: prevention and management. J Clin Virol.2011,52(1):4-10.

15. Wang J. Occupational Exposure Analysis and Control Strategy of Blood-borne Pathogens in Medical Staff-A Case Study of a Third-Class A Comprehensive Teaching Hospital. Southern Medical University,2013.

16. Sabine Wicker, Holger F Rabenau. Occupational Exposures to Bloodborne Viruses Among German Dental Professionals and Students in a Clinical Setting. Int Arch Occup Environ Health.83 (1), 77-83. 